\title{
THE AVAILABILITY OF CRIMINAL JURY TRIALS UNDER THE SIXTH AMENDMENT†
}

The Supreme Court's deepening concern for procedural safeguards ${ }^{1}$ has included concern for the availability of criminal jury trials. In a line of cases beginning with Duncan v. Kahanamoku $u^{2}$ and running through Kennedy v. Mendoza-Martinez ${ }^{3}$ and United States v. Barnett, ${ }^{4}$ the Court has shown a strong inclination to compel criminal jury trials in fringe areas of the criminal process previously thought to be free from any such constitutional directive.

Disconcertingly, the Court has failed to develop standards for imposing criminal jury trials in these new areas. Neither the old cases, which are now indirectly rejected, nor the modern cases, which point toward expansion, present a coherent view of the criminal jury requirement. This comment will explore the ideas about juries that can be gathered from the cases and attempt to develop a workable theory for the availability of criminal jury trials. Fundamental to this analysis is recognition of the tension between the individual's interest in a jury trial and government's interest in simpler procedures. ${ }^{5}$

\section{I.}

A criminal jury trial is required by the sixth amendment in "all criminal prosecutions." 6 Until recently, this phrase carried a most

$\dagger$ Chester Kamin, third year student at the University of Chicago Law School. For a related discussion of the Kennedy v. Mendoza-Martinez decision, see Comment, The Concept of Punitive Legislation and the Sixth Amendment: A New Look at Kennedy $v$. Mendoza-Martinez, 32 U. CHI. L. REv. 290 (1964) supra.

1 E.g., Escobedo v. Illinois, 378 U.S. 478 (1964); Jackson v. Denno, 378 U.S. 368 (1964); Silver v. New York Stock Exchange, 373 U.S. 341, 363 (1963); Fay v. Noia, 372 U.S. 391 (1963); Gideon v. Wainwright, 372 U.S. 335 (1963); Townsend v. Sain, 372 U.S. 293 (1963); Mapp v. Ohio, 367 U.S. 643 (1961); Beacon Theatres, Inc. v. Westover, 359 U.S. 500, 510-11 (1959).

2327 U.S. 304 (1963).

3372 U.S. 144 (1963).

4376 U.S. 681 (1964).

5 of course the government's potential interest in jury trials in ordinary criminal cases has been recognized. Adams v. United States, 317 U.S. 269, 277 (1942); Patton v. United States, 281 U.S. 276, 312 (1930); United States v. Igoe, 331 F.2d 766 (1964).

6 U.S. Const. art. III, \& 2, cl. 3: "The Trial of all Crimes, except in Cases of impeachment, shall be by Jury; and such Trial shall be held in the State where the said Crimes shall have been committed; but when not committed within any State, the Trial shall be at such Place or Places as the Congress may by Law have directed." U.S. CoNST. 
narrow and technical meaning. Certain cases clearly criminal in other senses of the word-criminal contempt ${ }^{7}$ and petty crimes ${ }^{8}$ for examplewere exempted from its scope, as were serious crimes committed or tried under special circumstances-in the armed forces, ${ }^{9}$ in American possessions, ${ }^{10}$ and in American consulates. ${ }^{11}$ Similarly exempted were fines and forfeitures for administrative violations which were serious enough to be crimes but which the legislature chose to enforce by "civil means." 12 And narrow construction barred juries where the state imposed such

amend. VI: "In all criminal prosecutions, the accused shall enjoy the right to a speedy and public trial, by an impartial jury of the State and district wherein the crime shall have been committed, which districts shall have been previously ascertained by law, and to be informed of the nature and cause of the accusation; to be confronted with the witnesses against him; to have compulsory process for obtaining witnesses in his favor, and to have the Assistance of Counsel for his defense." Schick v. United States, 195 U.S. 65, 78 (1904) holds that the term "all criminal prosecutions" was not intended to widen the term "trial of all crimes," that the purpose of the sixth amendment was solely to guarantee certain features of jury trials. For a history of the sixth amendment, see Frankfurter and Corcoran, Petty Federal Offenses and the Constitutional Guaranty of Trial by Jury, 39 FARv. L. Rev. 917, 969-75 (1926). For criticism of this article, see Kaye, Petty Offenders Have No Peers!, 26 U. CHI. L. Rev. 245 (1959). As for the relationship between the sixth amendment and the fifth amendment, United States v. Zucker, I61 U.S. 475, 480-82 (1896), makes clear that the sixth amendment's operative words, "all criminal prosecutions," are narrower in scope than the fifth amendment's provision against self-incrimination "in any criminal case." The grand jury provision for "capital or otherwise infamous crimes" is, of course, narrower than "criminal prosecution." Whether the sixth amendment jury requirement now applies to state as well as federal proceedings is outside the scope of this comment. $C f$. Gideon v. Wainwright, 372 U.S. 335 (1963).

7 United States v. Barnett, 376 U.S. 681, 694 n.12 (1964); Green v. United States, 356 U.S. 165 (1958); In re Debs, 158 U.S. 564 (1895).

8 District of Columbia v. Clawans, 300 U.S. 617 (1937); District of Columbia v. Colts, 282 U.S. 63 (1930); Schick v. United States, 195 U.S. 65 (1904); Callan v. Wilson, 127 U.S. 540 (1888).

9 Kahn v. Anderson, 255 U.S. 1 (1920); Ex parte Reed, 100 U.S. 13 (1877); Dynes v. Hoover, 61 U.S. 65 (1857).

10 Hawaii v. Mankichi, 190 U.S. 197, 215-216 (1903). Cf. Downes v. Bidwell, 182 U.S. $244,270-271,280-281$ (1901) (revenue power in territories).

11 In re De Ross, 140 U.S. 453, 465 (1890).

12 Helvering v. Mitchell, 303 U.S. 391 (1938) (double jeopardy); Oceanic Steam Navigation Co. v. Stranahan, 214 U.S. 320, 339 (1909); Hepner v. United States, 213 U.S. 103, 107-108 (1909) (and cases cited at 107-08) (directed verdict against defendant); United States v. Zucker, 161 U.S. 475, 481 (1896) (confrontation of witnesses); Passavant v. United States, 148 U.S. 214, 221-222 (1893); Bartlett v. Kane, 57 U.S. 263 (1853); United States v. La Vengeance, 3 U.S. 297 (1796); Olshausen v. CIR, 273 F.2d 23 (1960). Cf. License Tax Cases, 72 U.S. 462 (1866). But cf. Union Ins. Co. v. United States, 73 U.S. 759 (1867) (civil jury for federal forfeiture on land); Regal Drug Corp. v. Wardell, 260 U.S. 386 (1922); United States v. White, 106 U.S. 561 (1883) (civil jury to revoke land patent for fraud); Confiscation Cases, 74 U.S. 454 (1868). See also Van Oster v. Kansas, 272 U.S. 465,469 (1926) (no jury required for state forfeiture). 
disabilities for wrongdoing as loss of licenses, ${ }^{13}$ loss of right to receive mail, ${ }^{14}$ loss of employment, ${ }^{15}$ loss of child custody, ${ }^{16}$ protective custody of juveniles, ${ }^{17}$ denaturalization, ${ }^{18}$ and deportation. ${ }^{19}$

The many cases rigidly confining the sixth amendment were decided on a number of different theories. Criminal contempts could be punished without jury, it was said, because of powers implied "to our courts of justice, from the nature of their institution." 20 Offenses committed in the military were triable without jury because they were within the jurisdiction of courts-martial, which derived power under article I, section 8 and article II, section 2 and were "independent" of requirements for article III courts. ${ }^{21}$ Offenses overseas could be tried in American consulates without a jury because juries were not one of the "fundamental" protections of the Constitution which extended overseas.22 Fines for administrative violations could be collected in court without a criminal jury trial because the United States in these cases was merely a "creditor."23 Admiralty forfeitures for crimes were enforceable without juries because they were "civil causes in admiralty." 24 Aliens could be deported for wrongdoing with no jury trial because deportation was a matter of "regulating" the conditions of residence, not of "punishing"

13 Ex parte Wall, 107 U.S. 265 (1882) (disbarment); Board of Trade v. Wallace, 67 F.2d 402, 407 (1933) (commodity market suspensions); Farmer's Livestock Commission Co. v. United States, 54 F.2d 375, 378 (7th Cir. 1931); FCC v. American Broadcasting Co., 110 F. Supp. 374, aff'd, 347 U.S. 284 (1953) (broadcasting license).

14 Donaldson v. Read Magazine, Inc., 333 U.S. 178, 191-192 (1948).

15 Angilly v. United States, 199 F.2d 642, 644 (2d Cir. 1952) (A. Hand, J.).

16 In re Lambert, 203 F.2d 607, 609-10 (D.C. Cir. 1953).

17 Cf. United States ex rel. Yonick v. Briggs, 266 Fed. 434 (W.D. Pa. 1920) (state proceedings); Ex parte Januszewski, 196 Fed. 123, 127, 131 (S.D. Ohio 1911) (stato proceedings).

18 Luria v. United States, 231 U.S. 9 (1913) (equity suit).

19 Mahler v. Eby, 264 U.S. 32, 39 (1924); Bugajewitz v. Adams, 228 U.S. 585, 591 (1913); Zakonaite v. Wolf, 226 U.S. 272 (1912); Johannessen v. United States, 225 U.S. 227 (1912); United States ex rel. Turner v. Williams, 194 U.S. 279 (1904); accord, Fong Yue Ting v. United States, 149 U.S. 698, 730 (1893); cf. Yakus v. United States, 321 U.S. 414,447 (1944); Ng Fung Ho v. White, 259 U.S. 276 (1922); Wong Wing v. United States, 163 U.S. 228 (1896).

20 Ex parte Robinson, 86 U.S. 505, 510-11 (1873); Ex parte Kearney, 20 U.S. 38, 43-44 (1822); United States v. Hudson, II U.S. 32, 34 (1812).

21 Dynes v. Hoover, 61 U.S. 65,79 (1857).

22 In re Ross, 140 U.S. 453, 465 (1890).

23 Hepner v. United States, 213 U.S. 103, $107-08$ (1909). Some fines could constitutionally be collected without any court proceeding at all, by application of sanctions already in the hands of the administrator. Oceanic Steam Navigation Co. v. Stranahan, 214 U.S. 320 (1909). These cases were used to uphold license suspensions imposed without any judicial intervention. See cases cited note 13 supra.

24 United States v. La Vengeance, 3 U.S. 297, 301 (1796). 
crime. ${ }^{25}$ Petty crimes could be punished with no jury because the Constitution incorporates such common-law usages. ${ }^{26}$

But the Supreme Court never developed a general theory that could be used to decide all sixth amendment claims to criminal jury trials. Under the sway of rigid concepts and historical practice, it dealt with each area of decision in utter isolation. Thus as the post-World War II Court moved to enlarge the constitutional domain of the criminal jury, it was faced with the necessity of developing a theory to guide the expansion. The old cases provided almost nothing to go on.

II.

Although faced with the need to articulate guidelines for its expansion of the jury requirement, the Court has failed, in consummate tradition, to do so. The cases show, however, that because the Court has come to regard the criminal jury trial as a fundamental constitutional safeguard, historical barriers to the use of juries are in jeopardy. ${ }^{27}$

The expansion began in 1946 with the first of several cases restricting the criminal jurisdiction of military tribunals. ${ }^{28}$ Employing both statutory and constitutional techniques, the Court rejected key sixth amendment cases and magniloquently elevated juries to the top of the hierarchy of constitutional concerns. In Duncan v. Kahanamoku $u^{29}$ two civilians unconnected with the military ${ }^{30}$ were tried by military commission in war-

25 Zakonaite v. Wolf, 226 U.S. 272, 275 (1912) (and cases cited therein).

26 Thus when the offense in question was punished without a jury at common law and in colonial experience, for example, prostitution, it need not now be tried by jury. Bailey v. United States, 98 F.2d 306 (D.C. Gir. 1938). Similarly, since prosecutions for conspiracy and criminal libel were customarily tried by jury, the sixth amendment requirement applies to those offenses. Callan v. Wilson, 127 U.S. 540 (1888); In re Dana, 6 Fed. Cas. 1140, 1142 (No. 3554) (S.D.N.Y. 1873). Where the petty offense did not exist before 1787, such as selling oleomargarine, the Court speculated whether such an offense would have been prosecuted by jury had it existed. The moral gravity of the offense and the amount of punishment prescribed were treated as the key factors. Schick v. United States, 195 U.S. 65 (1904). In a later case, District of Columbia v. Clawans, 300 U.S. 617, 625 (1937), the Court, in dictum, remarked that offenses too petty for jury trial at common law might require.a jury now if the penalty for the offense had grown more severe, either in absolute measurement or relative to contemporary mores.

27 A parallel movement to expand the availability of civil juries under the seventh amendment occurred. See Simler v. Conner, 372 U.S. 221 (1963); Dairy Queen, Inc. v. Wood, 369 U.S. 469, 472 (1962); Beacon Theatres, Inc. v. Westover, 359 U.S. 500, 510-11 (1959).

28 During the war, the Court had been much more willing to concede that military tribunals had jurisdiction. E.g., Ex parte Quirin, 317 U.S. 1 (1942) (military tribunal for saboteurs). But cf. Ex parte Endo, 323 U.S. 283 (1944).

29327 U.S. 304 (1946).

30 The Court disregarded Duncan's employment in a Navy Yard. 
time Hawaii for non-military crimes. ${ }^{31}$ By authority of the Act of Congress establishing the Hawaiian government, civil courts had been replaced with military commissions during the worst of the emergency, and certain crimes had been reserved for military trials after the courts were reopened. The Supreme Court, through Mr. Justice Black, held that the trials were unauthorized by Congress.

The Justice sidestepped a venerable sixth amendment case, Hawaii $v$. Mankichi, ${ }^{32}$ which held that only fundamental constitutional rights took effect in territories like Hawaii and that conviction by a less-thanunanimous jury did not involve a fundamental right. He avoided reopening these issues by assuming that Congress in establishing the Hawaiian government had intended to provide constitutional protection in full force. This assumption had been argued and rejected in Mankichi, which involved, however, somewhat different statutory language.

The Court concluded that Congress' grant of authority to convoke military tribunals should be construed narrowly in the light of historical Anglo-American "principles and practice." That historical standardwhich may or may not be a constitutional standard-forbade general substitution of military tribunals for civil courts except in extreme emergencies. The overruling of Hawaii $v$. Mankichi, though foreshadowed, would await another day.

The Court showed deep concern about procedural safeguards found in courts of law but lacking in military tribunals, terming them "prized privileges of our system of government."33 Yet the jury trial-so highly touted in later cases-was scarcely mentioned, Mr. Justice Black concentrating his fire on the arbitrariness of military punishments, the inferiority of rules of evidence and procedure, and the absence of review either by appellate courts or by habeas corpus. ${ }^{34}$

In the next case limiting court-martial jurisdiction, the grounds were also statutory but quite narrow. The question in United States ex rel. Hirschberg $v$. Cooke, ${ }^{35}$ was whether the Navy could court-martial an enlisted man for a crime committed during a prior enlistment. The Court, again through Mr. Justice Black, unanimously held that Congress had not authorized the Navy to provide for courts-martial in such situations. It stressed that Navy regulations until 1932 had not assumed

31 The crimes were embezzling stock and assault. Duncan's assault on two armed sentries at the Navy Yard was prosecuted under military nomenclature as "violations of military orders." 327 U.S. at 310 .

32190 U.S. 197 (1903).

38327 U.S. at 307.

34 Id. at 309-10. Mr. Justice Murphy's concurrence mentions the jury with similar brevity. Id. at 325 .

35336 U.S. 210 (1949). 
jurisdiction over offenses in prior enlistments and that Army regulations still carried that limitation. ${ }^{36}$

Six years after Duncan v. Kahanamoku the Court in Madsen v. Kinsella $a^{37}$ faced another complaint that a civilian had been improperly tried by military authorities. This time a wife accused of murdering her serviceman husband while both were stationed in Germany had been tried by a military commission. She objected to trial by military commission rather than by court-martial, which, she conceded, would have been proper. The Court held that court-martial jurisdiction was not exclusive. and that the commission's exercise of jurisdiction was proper.

Justice Black alone dissented. He argued in a two-paragraph opinion that the failure of Congress to authorize trial by commission was fatal:

Whatever may be the scope of the President's power as Commander-in-Chief of the fighting armed forces, $I$ think that if American citizens in present-day Germany are to be tried by the American Government, they should be tried under laws passed by Congress and in Courts created by Congress under its constitutional authority. ${ }^{38}$

Once again Black's hostility to military trials was evident, but his argument did not logically extend to curtailing courts-martial since their legislative basis was firm. Yet he was shortly to attack courts-martial with constitutional weapons.

This attack opened in United States ex rel. Toth v. Quarles. ${ }^{39}$ Five months after an airman had been honorably discharged from service, military police arrested him in Pittsburgh for a murder committed in Korea while he was still under colors. The ex-airman challenged the arrest by habeas corpus and asked the Court whether Congress could establish court-martial jurisdiction over ex-servicemen who had severed all relationship to the military without violating the constitutional right to a jury trial in "all criminal prosecutions."

Military jurisdiction over ex-servicemen for crimes in service had never been tested against the Constitution, probably because the statute

36 The Court rejected as unimportant the circumstance that the defendant was in the Navy the whole time save for several hours between discharge and reenlistment, showing concern for civilian subjection to military jurisdiction: "For if that interpretation is correct, court-martial jurisdiction would be satisfied if a sailor was merely in the Navy' when the offense was committed and when brought before the court-martial, regardless of the duration of any interim period out of the naval service . . . " Moreover, said the Court, such a result would make court-martial jurisdiction "whimsical and uncertain," for the enlistee might not reenlist or might reenlist in the Army. Only if he reenlisted in the Navy would he be tried by court martial. "Jurisdiction to punish rarely, if ever, rests upon such illogical and fortuitous contingencies." $I d$. at 213-14.

37343 U.S. 341 (1952).

38 Id. at 372 .

39350 U.S. 11 (1955). 
authorizing jurisdiction had only recently been enacted.40 But Kahn $v$. Anderson, ${ }^{41}$ a World War I case, had approved military jurisdiction to try a dishonorably discharged serviceman, still a military prisoner, for a crime committed after discharge but during military custody.

Writing for a six to three majority, ${ }^{42} \mathrm{Mr}$. Justice Black admitted the authority of Kahn, but distinguished the case on its facts without analysis. The case was decided instead by reference to the "natural meaning" of the Article I power to regulate the armed forces, ${ }^{43}$ which "would seem to restrict court-martial jurisdiction to persons who are actually members or part of the armed forces." 44

Narrow construction of court-martial jurisdiction was also impelled by the vulnerability of courts-martial to improper military pressures and by their lack of trial by jury. Justice Black voiced the virtues of juries with fervor:

Juries fairly chosen from different walks of life bring into the jury box a variety of different experiences, feelings, intuitions and habits. Such juries may reach completely different conclusions than would be reached by specialists in any single field, including specialists in the military field. On many occasions, fully known to the Founders of this country, jurors-plain people-have manfully stood up in defense of liberty against the importunities of judges and despite prevailing hysteria and prejudices. . . . Unfortunately, instances could be cited where jurors have themselves betrayed the cause of justice by verdicts based on prejudice or pressures. In such circumstances independent trial judges and independent appellate judges have a most important place under our plan since they have power to set aside convictions. 45

40 The jurisdiction was authorized by Uniform Code of Military Justice art. 3(a), ch. 169, 64 Stat. 109 (1950) (now 10 U.S.C. $\S 803$ (a) (1958)), which provided for courtmartial jurisdiction over ex-servicemen only for serious crimes committed in service which no other American court had jurisdiction to punish.

41255 U.S. 1 (1921).

42 There were two dissents, one by Mr. Justice Reed joined by Justices Burton and Minton, and one by Minton joined by Burton.

43 Art. I, § 8, cl. 14.

44350 U.S. 11,15 (1955).

45 Id. at 18-19. Moreover, Mr. Justice Black said, the necessary and proper clause does not enlarge article $I, \S 8$ to this degree. "It is impossible to think that the discipline of the Army is going to be disrupted, its morale impaired, or its orderly process disturbed, by giving ex-servicemen the benefit of a civilian court trial when they are actually civilians . . . . Army discipline will not be improved by court-martialing rather than trying by jury some civilian ex-soldiers who have been separated from the service for months, years or perhaps decades. Consequently considerations of discipline provide no excuse for new expansion of court-martial jurisdiction at the expense of the normal and constitutionally preferable system of trial by jury." 350 U.S. at 22-23 (citing Dimick v. Schiedt, 298 U.S. 474, 485-86 (1934), a civil jury case). 
Toth's generous praise of the jury could scarcely be surpassed, but it was equalled two years later in Reid $v$. Covert.46 Continuing the attack on court-martial jurisdiction, the Court held that wives accompanying servicemen on duty abroad could not be subject to trial by court-martial for capital crimes committed there. Mr. Justice Black, on behalf of a plurality ${ }^{47}$ including Warren, Douglas and Brennan, declared that the case was governed by Toth, as well as by Duncan $v$. Kahanomoku. ${ }^{48}$

The Court ignored Madsen v. Kinsella, ${ }^{49}$ in which five years earlier it had tacitly approved of court-martial jurisdiction over a military dependent. Nor did Mr. Justice Black reconcile his present opinion with his dissenting position in Madsen that Congress had power to extend court-martial jurisdiction to dependents. But he did face squarely cases like Hawaii $v$. Mankichi, ${ }^{50}$ which postulated that only fundamental rights of the Constitution extend overseas. He flatly rejected both the postulate about fundamental rights and the notion that juries were not fundamental, finding another opportunity to praise the jury:

Looming far above all other deficiencies of the military trial, of course, is the absence of trial by jury before an independent judge after indictment by a grand jury. ${ }^{51}$

Blackstone wrote in his Commentaries: "[T]he trial by jury ever has been, and I trust ever will be looked upon as the glory of the English law. ... [I]t is the most transcendent privilege which any subject can enjoy or wish for, that he cannot be affected wither in his property, his liberty, or his person, but by the unanimous consent of twelve of his neighbors and equals." Trial by jury ... has served and remains one of our most vital barriers to governmental arbitrariness. These elemental procedural safeguards were embedded in our Constitution to secure

Because of the strengths of jury trials and the weaknesses of courts-martial, "determining the scope of the constitutional power of Congress to authorize trial by courtmartial presents another instance calling for limitation to 'the least possible power adequate to the end proposed." 350 U.S. at 23 (citing Anderson v. Dunn, 19 U.S. (6 Wheat.) 204, 230-31 (1821)).

46354 U.S. 1 (1957). The Court had decided this case once before, 351 U.S. 487 (1956), upholding court-martial jurisdiction five to three with Frankfurter reserving opinion. On rehearing, Harlan switched his vote, Brennan replacing Minton voted to strike down the statute, and Whittaker replacing Reed did not participate.

47 Frankfurter and Harlan each wrote separate concurrences stressing the capital nature of the case. Clark and Burton dissented, relying on In re Ross, 140 U.S. 453 (1890).

48327 U.S. 304 (1946). The Court relied also on Ex parte Milligan, 71 U.S. 2 (1866).

49343 U.S. 341 (1952). See text accompanying note 37 supra.

50190 U.S. 197 (1903). See also In re Ross, 140 U.S. 453 (1891) (denying trial by jury in American consulates abroad also expressly disapproved).

51354 U.S. 1, 37 (1957). 
their inviolateness against the passing demands of expediency or convenience. ${ }^{52}$

As the attack on court-martial jurisdiction proceeded, high praise for the jury continued. In Lee v. Madigan ${ }^{53}$ the Court held that an ex-serviceman who had been dishonorably discharged and imprisoned by court-martial for one offense could not be tried by court-martial for a second crime committed in a mainland military stockade while he was under sentence for the earlier offense. The technical question concerned a statute which prohibited court-martial for murder in the United States "in time of peace." The Court seemed untroubled by the similar World War I case, Kahn v. Anderson, ${ }^{54}$ which had held in part that "peace" meant peace officially declared. Though the Court in the Toth case had given lip-service to the authority of Kahn, it now dismissed the Kahn definition of peace as dictum and accordingly treated the question as open. To define "peace," the Court returned to the theme of Toth and Reid-that court-martial jurisdiction must be narrowly construed because courts-martial are vastly inferior to jury trials. "Peace" now meant a cessation of hostilities. While the Court explicitly rejected only that part of Kahn which defined peace, few could think that Kahn remained authority for the general proposition that ex-servicemen could constitutionally be court-martialed for crimes done as military prisoners.

In Lee, as in Toth and Reid, praise for the jury was profuse, but for the first time the author was not Mr. Justice Black but Mr. Justice Douglas: "The most significant of these [constitutional guarantees for the accused] is the right to trial by jury, one of the most important safeguards against tyranny which our law has designed." 55

Now the attack on court-martial jurisdiction over those not in active service was complete, save for a mopping up action. This came a year later in the form of three companion cases. In Kinsella $v$. United States ex rel. Singleton, ${ }^{56}$ the Reid case was repeated except that the dependent

52 Id. at 9-10.

53358 U.S. 228 (1959). Justices Harlan and Clark dissented. Justice Frankfurter took no part.

54255 U.S. 1 (1920). See text accompanying note 41 supra.

65 358 U.S. 228, 234 (1959).

56361 U.S. 234 (1960). Assuming that Reid and Toth, to which he had dissented, were right for capital cases, Justice Clark concluded that a capital-non-capital distinction could not be maintained. In Reid, Justice Clark had based his dissent on administrative necessity and the lack of feasible alternatives for disposing of the servicerelated crimes. He returned to that issue, pointing out that the number of such cases is small and hence discipline would not be endangered. Clark also intimated as dictum that due process may now include the right to a criminal jury trial.

Frankfurter and Harlan, true to their concurrences in Reid, dissented, saying that in the balance of interests a non-capital case ought to be triable by court-martial. Whittaker and Stewart concurred in the result because the dependent's status was not one of close connection to the armed forces. 
was charged with a non-capital offense. Grisham $v$. Hagan, ${ }^{57}$ like Reid, was capital, but the defendant asserting his right to a jury trial was an American civilian employed at an overseas Army installation. McElroy $v$. United States ex rel. Guagliando ${ }^{58}$ presented a non-capital variation of Grisham. On the authority of Toth and Reid, court-martial jurisdiction in all three cases was held to be forbidden by the Constitution.

Three years after the last court-martial cases came Kennedy v. MendozaMartinez.59 There the Court held invalid a statute which, without providing for jury trial, denationalized citizens who left the country to evade the draft. Since loss of citizenship was to take place automatically upon the evader's departure from the country, without any procedures at all, the statute was deemed to violate not only the sixth amendment's jury trial provision but the fifth amendment's provision for indictment and notice.

In Mendoza, two cases were consolidated for decision, each with an extensive history. In one, Kennedy v. Mendoza-Martinez, a dual-national of the United States and Mexico had gone to Mexico during World War II to evade the draft. Returning after the war, he pleaded guilty in federal court to evading the draft. Afterward, the Government sought to deport him as an alien, contending that his departure from the country to avoid military service had automatically stripped him of American citizenship. Mendoza exhausted his administrative remedies and then asked for a judicial declaration that he remained a citizen on the ground that Congress did not have power to extinguish citizenship for draft evasion. After the district and circuit courts refused this relief, the Supreme Court granted certiorari.

- The Court vacated judgment and remanded the case to the district court for reconsideration in the light of the newly decided Trop $v$. Dulles, ${ }^{60}$ where the Court had held that Congress lacked power to denationalize a citizen convicted of desertion in wartime. The district

57361 U.S. 278 (1960). Clark again for the majority held that the case was governed by Reid. He stressed the lack of administrative necessity, adverting to the small number of such civilian employees and the possibility of requiring such employees to submit to military jurisdiction as a condition of employment. Frankfurter and Harlan, grandly consistent, concurred in result because the case was capital. Whitaker and Stewart dissented, arguing that an employee by status was in matters of discipline more closely connected to the service than were dependents.

58361 U.S. $281(1960)$. Clark again for the majority treated the case like Singleton; a capital-non-capital distinction could not stand. Frankfurter and Harlan, as expected, dissented because the case was non-capital and the balance of interests shifted accordingly. Whitaker and Stewart again dissented for the reasons given about an employee's status in Grisham.

59372 U.S. 144 (1963).

60356 U.S. 86 (1958). 
court then held that Congress lacked power to denationalize Mendoza. On appeal, the Supreme Court again remanded for the district court's determination of a minor question of collateral estoppel. On the second remand, there appeared the first glimmer of the procedural issue which was eventually to dominate the case. The district court now found another constitutional defect in the statute: it was an "essentially penal" statute and therefore the administrative proceedings it provided did not afford Mendoza "procedural due process."61

The case decided with Mendoza was Rusk $v$. Cort. ${ }^{62}$ During the Korean conflict, Cort had remained in Europe in spite of orders to report to a draft board in Massachusetts. Later his application for a return passport was denied on the ground that he had forfeited his citizenship by draft evasion. Remaining in Europe, Cort sought a judicial declaration that he was still a citizen. A three-judge district court granted this relief, holding that Congress did not have power to enact this denationalization statute. That court perceived "no substantial difference between the constitutional issue in the Trop case and the one facing us." 63 In contrast to the district court's decision in Mendoza, the district court here did not find that the statute denied due process. Its holding was limited to the substantive question decided in Trop: that Congress lacked power to enact the denationalization statute.

The Trop case, which controlled both lower court decisions to be reviewed in $M$ endoza, had aroused keen interest. The Court had divided into three opinions and many doctrines without producing a majority opinion. Mr. Chief Justice Warren, joined by Justices Black, Douglas, and Whitaker, contended that Congress did not have power to take away citizenship under any circumstances and that, even if it did, this exercise would constitute "cruel and unusual punishment" for desertion. Mr. Justice Brennan concurred in the result on the ground that denationalization may be employed only for special regulatory purposes absent in the case of desertion. Mr. Justice Frankfurter, for the rest of the Court, dissented, arguing that denationalization was not technically punishment, let alone cruel and unusual punishment, and that its employment was reasonably related to the war power.

Interest in Trop was keen also because the result seemed to contradict the Court's holding in Perez $v$. Brownell, ${ }^{64}$ decided the same day. There, the Court upheld five to four a provision denationalizing citizens who

61 Judgment at 192 F. Supp. 1 (1961) (opinion unreported).

62369 U.S. 367 (1960), the same litigation, dealt with a question of the availability of declaratory judgments under the 1952 Immigration and Nationality Act.

63 Sub nom. Cort v. Herter, 187 F. Supp. 683, 687 (1960).

64356 U.S. 44 (1958). 
voted in foreign elections. Only Mr. Justice Brennan found a way to distinguish between desertion and foreign voting; he alone voted with the winning side in both Trop and Perez. The two cases created considerable uncertainty, but surely Mendoza would bring a clarification of the Court's position on involuntary denationalization.

Thus, Mr. Justice Goldberg's majority opinion in Mendoza was greeted with surprise:

We have come to the conclusion that there is a basic question in the present cases, the answer to which obviates a choice here between the powers of Congress and the constitutional guarantee of citizenship. That issue is whether the statutes here, which automatically-without prior court or administrative proceedings-impose forfeiture of citizenship, are essentially penal in character, and consequently here deprived the appellees of their citizenship without due process of law and without according them the rights guaranteed by the Fifth and Sixth Amendments, including notice, confrontation, compulsory process for obtaining witnesses, trial by jury, and assistance of counsel. ${ }^{65}$

The,Court conceded that the existing provisions for administrative and judicial review of denationalization "after the fact" may satisfy due process. But if the statute is penal, said the Court, more than due process is required. All the criminal provisions of the fifth and sixth amendments are called into play, including the criminal jury trial. ${ }^{66}$ The penal nature of the statute was demonstrated by expressions of congressional intent, though the Court was satisfied that other criteria for punitiveness developed in ex post facto cases ${ }^{67}$ would also be met. The Court under-

65372 U.S. 144, 163-64 (1963). This proposition is repeated three more times: "We hold $\$ \S 401(j)$ and $439(a)(10)$ invalid because in them Congress has plainly employed the sanction of deprivation of nationality as a punishment-for the offense of leaving or remaining outside the country to evade military service-without affording the procedural safeguards guaranteed by the Fifth and Sixth Amendments." 372 U.S. at 165-66 (Emphasis added.) "[T] to every congressional enactment relating to the provisions in question dating back to 1865 establish that forfeiture of citizenship is a penalty for the act of leaving or staying outside the country to avoid the draft. This being so, the Fifth and Sixth Amendments mandate that this punishment cannot be imposed without a prior criminal trial and all its incidents. . . . If the sanction these sections impose is punishment, and it plainly is, the procedural safeguards required as incidents of a criminal prosecution are lacking. We need go no further." 372 U.S, at 167 (Emphasis added.) "We conclude, for the reasons stated, that $\S \S 401(\mathrm{j})$ and $439(\mathrm{a})(10)$ are punitive and as such cannot constitutionally stand, lacking as they do the procedural safeguards which the Constitution commands. . . . What we hold is only that, in keeping with this cherished tradition [of the Magna Carta] punishment cannot be imposed 'without due process of law:" 372 U.S. at 186 (Emphasis added.)

66 Id. at 167.

67 Id. at 167-69. 
took no sustained discussion of the virtues of juries but merely alluded to an abiding principle dating back to Magna Carta. ${ }^{68}$

The decision in Mendoza confirms the impression that the Court is moving away from the traditional understanding of the sixth amendment. While the court-martial cases showed a growing regard for the jury and a rejection of traditional decisions, the cases could be viewed as close ones even within the hodge-podge outline of the traditional cases. The offenses were felonies, and thus the defendants were entitled by tradition to be tried by jury. The sanctions, death and imprisonment, were those traditionally associated with the punishment of crime. The question was narrow and traditional: whether these citizens were so closely related to the service that a court-martial could take criminal jurisdiction.

Although the Court through the years had never articulated a general theory of the jury requirement, one fact appeared from the old cases. Sanctions like denationalization, which were not customary in punishing crime, could be enforced without a jury trial. ${ }^{69}$ Since the Mendoza court held that denationalization now required a jury trial, juries for other non-criminal sanctions may logically be reconsidered. In light of the Court's high regard for jury trials, ${ }^{70}$ it seems likely that the expansion will be dramatic.

It may be objected that Mendoza will have little effect on sixth amendment doctrine. ${ }^{71}$ After all, the opinion was a surprising result of a clash over substantive issues. Seven members of the Court joined in opinions that reached the substantive question-Congress' power to denationalize. Only the Chief Justice joined wholeheartedly in Mr. Justice Goldberg's procedural disposition of the case. Yet the Chief Justice himself stated emphatically in Trop and in his Perez dissent that Congress lacked power to denationalize. Presumably these views had not changed, so the Chief Justice's refusal to join in the concurrences that reach the substantive issue was probably a matter of tactics. ${ }^{72}$

$68 \mathrm{Id}$. at 186.

69 See cases cited in notes $12-19$ supra.

70 This regard appears not only in the court-martial cases, but in the civil cases cited note 27 supra. Cf. Speiser v. Randall, 357 U.S. 513 (1958) (summary procedure invalid to deny state tax exemption to subversive); Kingsley Books, Inc. v. Brown, 354 U.S. 436, 447-48 (1957) (dissenting opinion, Brennan, J.) (jury required in obscenity proceedings).

71 In Schneider v. Rusk, 377 U.S. 163 (1964), Mendoza is cited as if relevant to the substantive issue of Congress' power to denationalize. See Apetheker v. Rusk, 378 U.S. 500 (1964); Comment, 32 U. CHI. L. REv. 290 (1965); The Supreme Court, 1963 Term; 78 HaRv. L. REv. 143, 187 (1964).

72 For example, Goldberg might have gone over to the dissenters if Warren had left Goldberg's opinion devoid of wholehearted support. More likely, Warren was trying to be courteous. 
If so, the Court was divided four against four on the substantive issue. Goldberg's was the key vote. Why he did not reach the substantive issue can only be a matter of speculation. ${ }^{73}$ But if only one justice felt strongly about the majority opinion, its future influence on sixth amendment doctrine would be questionable.

However, doubts about the influence of Mendoza are reduced because of its employment in Barnett $v$. United States. ${ }^{74}$ The Governor of Mississippi had demanded a jury trial on a charge of criminal contempt for disobeying Court of Appeals orders to admit a Negro to the University of Mississippi. A majority of the Court, in an interlocutory appeal, denied this demand, since by tradition criminal contempts could be punished summarily.

But significant cracks now appeared in that tradition. A dissent by the author of Mendoza, Mr. Justice Goldberg, stated that criminal contempts were really part of the petty crimes exception to the sixth amendment -a dubious piece of history. ${ }^{75} \mathrm{~A}$ leading case had suggested that petty crimes which are punished more severely in modern times than previously should thereby lose their petty character and require jury trials.76 In light of a trend to punish contempts with unprecedented severity, Mr. Justice Goldberg concluded that serious, "non-trivial" contempts, like Barnett's, required a jury trial.

Goldberg employed Mendoza in two connections: first, to establish that criminal contempts are penal in the sense the term was used in Mendoza, and second, to rebut the contention that needs of judicial administration justified dispensing with the jury. The Justice quoted himself:

73 In Schneider v. Rusk, 377 U.S. 163 (1964), Goldberg joined the majority on the substantive issue that a naturalized citizen could not constitutionally be denaturalized for staying at length in her country of origin. This vote indicates that Goldberg is willing to strike down citizenship statutes. So Goldberg's opinion in Mendoza might have been an attempt at judicial restraint. That hypothesis is questionable, since the substantive issue that will be presented if the statute is appropriately amended is identical to that in Trop. As Mr. Justice Jackson has said, judicial restraint need not consist of "technical doctrines for postponing inevitable decisions." JAckson, THE Struggre for Judicial Supremacy, quoted in Freund, Constitutional Law, 108 (1954). Perhaps Goldberg felt, as in Silver v. New York Stock Exchange, 373 U.S. 341 (1963), that procedural protections are vital not only to the individual but to the Court as a way to avoid difficult substantive questions.

74 See note 7 supra. Mendoza was also relied on by counsel in Telephone News System, Inc. v. Illinois Bell Tel. Co., $220 \mathrm{~F}$. Supp. 621 (1963), where a jury trial was sought before telephone disconnection for illegal use. Discussed in text accompanying note 122, infra.

75 See Tefft, Barnett $v$. United States: 'Twas a Wondrous Victory, 1964 SuPREME CourT Revirw 123. See generally Frankfurter and Corcoran, Petty Federal Offenses and the Constitutional Guaranty of Trial by Jury, 39 HARv. L. REv. 917 (1926).

76 District of Columbia v. Clawans, 300 U.S. 617 (1937), discussed supra note 26. 
The imperative necessity for safeguarding [our cherished liberties] under the gravest of emergencies has existed throughout our constitutional history, for it is then, under the pressing exigencies of crises, that there is the greatest temptation to dispense with fundamental constitutional guarantees which, it is feared, will inhibit governmental action. 77

Mr. Justice Goldberg's dissent, joined in by the Chief Justice and Mr. Justice Douglas, was clearly intended to carry forward the expansive spirit of his Mendoza opinion. Mr. Justice Black, dissenting separately, also advocated a jury, but under a different constitutional theory.

Moreover, at least two members of the majority accepted Goldberg's premise that severe punishment for contempt requires a jury trial. A footnote stated: "some members of the Court are of the view that without regard to the seriousness of the offense, punishment by summary trial without a jury would be constitutionally limited to that penalty provided for petty offenses."78 While Goldberg would have required juries whenever the contempt was serious, a pre-trial determination, the footnote view would require juries whenever the penalty was severe, necessarily a post-trial determination. Thus no objection to summary trial could validly be raised at the outset, as Governor Barnett tried to do, but a penalty in excess of a "petty" level would apparently be" remitted if summarily imposed. If this half-loaf is acceptable to the three justices represented by Goldberg's dissent, they may collaborate with the majority justices responsible for the footnote. By limiting summary power in contempt, this new majority would take another step along the trial blazed by Mendoza and the court-martial cases. This prospect of further movement reaffirms the need for doctrinal guidance.

III.

In formulating a theory for the jury requirement it is essential to know what purposes are thought to be served by the criminal jury trial. The court-martial cases were long on praise for the jury but short on analysis. What analysis could be found was flimsy. The jury, it was said, is "better" than specialists at determining complicated issues.79 The jury is more impartial than specialists like military officers. ${ }^{80}$ The jury resists the "importunities of judges" and "prevailing hysteria and prejudices." 81 When it does not, the independent judges, whose impor-

77376 U.S. 681, 760 (1964).

78 Id. at 695.

79 United States ex rel. Toth v. Quarles, 350 U.S. 11, 18-19 (1955).

80 Ibid.

81 Ibid. 
tunities juries are so good at resisting, are there to reverse the conviction. ${ }^{82}$ The jury tries the defendant before his "neighbors and equals." 83 The jury is a barrier to governmental arbitrariness. ${ }^{84}$

Similar observations in legal literature have been advanced and attacked in the "fascinating and bitter" debate over the competence of the jury. ${ }^{85}$ That debate goes on, in part because both sides prefer value judgments to empirical evidence and in part because empirical evidence is inconclusive. So it is important to note that the Court's observations are at best partial or undemonstrated truths; at worst they are contradictory or simply wrong. That juries resist popular hysteria or judicial influence is a partial truth. The history of free speech and race relations shows it is not a whole truth. ${ }^{86}$ That juries are competent to try complicated issues is an undemonstrated assertion. ${ }^{87}$

That the jury opposes governmental arbitrariness is an internally contradictory assertion. The jury may resist arbitrary government in the sense that it can refuse to enforce harsh laws. ${ }^{88}$ But the same lawdispensing function frees the jury to refuse to enforce a good law to the letter where the particular result is harsh. The outcome of similar cases thus varies from defendant to defendant and from jury to jury in a way that contradicts our notion of a rational and even-handed system. This unevenness is the essence of one form of arbitrary government.

That juries try a man before his neighbors and equals is an assertion which is simply wrong. The defendant is not likely to be tried before his neighbors, because cities are large and faceless; he is not always tried before his equals, because educated persons usually fall in occupations excluded from jury service. 89

The weakness of argument in support of juries does not make a case for abolishing the criminal jury. The virtues of a jury are strong enough to justify its continued use where it already exists. But no clear mandate of morals or policy supports the transposition of the criminal jury to

82 Id. at 22-23.

83 Reid v. Covert, 354 U.S. 1, 9-10 (1957).

84 Id. at 36-37.

85 Zeisel \& Kalven, The Jury, the Judge, and the Crimtnal Case ch. 1 (to be published 1965).

86 Broeder, The Functions of the Jury: Facts or Fictions?, 21 U. ChI. L. REv. 386, 414 (1954).

87 See Williams, The Proof of Gullt 236-43 (1958); Holmes, Law in Science and science in Law in Collected Legal Papers 237-38 (1920). Compare Dicey, Law AND THE Construtution 394 (9th ed. 1948).

88 DevLIN, TRIAL BY JURY 160-61 (1956) (The Jury as a Safeguard Against Repugnant Law).

89 Williams, op. cit. supra note 88 , at 236-43; BROEDER, op. cit. supra note 86 , at 397, 400. See, e.g., ILL. REv. Stat. ch. 78, $\$ 4$ (1935) (Illinois jury exemptions). 
new fields of law. These other fields must afford due process, ${ }^{90}$ which assures notice, hearing, and possibly other clearly beneficial protections like right to counsel. ${ }^{91}$ It is unclear what juries would add.

Thus, the Court's movement to extend the jury trial requirement is apparently derived from an ill-defined impulse to protect individuals from unfair governmental action. The ambiguity of jury policy should inspire caution in this movement.

Mendoza suggests one way of formulating a general theory: when the statute is "penal," it may not be enforced without a jury trial. If "penal" is taken at its dictionary meaning-to impose a disability for crime or wrongdoing-this statement makes a sensible beginning. What draws attention to the need for procedural protection is the Government's attempt to take action against an individual in consequence of his wrongdoing. ${ }^{92}$ Thus, penal in this sense is a proper threshold word.

But the use of the word "penal" can lead to major complications. "Penal" as a constitutional characterization of statutes has been used primarily as one pole of a "penal-regulatory" distinction which has been prominent in ex post facto and bill of attainder cases since Cummings $v$. Missouri. ${ }^{93}$ The majority opinion in Mendoza probably understands "penal" as part of this distinction, and Mr. Justice Stewart's dissent clearly does. ${ }^{94}$ The Court has used the distinction to ascertain whether a statute imposing a disability retrospectively violates the ex post facto or

90 The fifth amendment requirement of due process might provide various sixth amendment protections even though the circumstances would not bring the sixth amendment as a whole into play. For example, an administrative "fair hearing" might in some instances require right to counsel, or other sixth amendment protections like compulsory process for favorable witnesses or right to confront hostile witnesses. United States ex rel. Castro-Louizon v. Zimmerman, 94 F. Supp. 22, 25-26 (E.D. Pa. 1950), cited approvingly in I Davis, Administrative Law \$ 8.10, at 557-58 (1958); cf. Barresse v. Ryon, 189 F.Supp. 449, 452 (1960) (counsel required in deportation on statutory grounds). But see In re Groban, 352 U.S. 330 (1957).

91 "Of all the rights that an accused person has, the right to be represented by counsel is by far the most pervasive, for it affects his ability to assert any other rights he may have." Schaefer, Federalism and State Criminal Procedure, 70 HARv. L. REv. I, 8 (1956).

82 In certain penal proceedings a jury trial has been sought on the basis of the seventh amendment. In the old cases where sanctions were outside the traditional criminal sphere, the Government was treated as merely another private party and jury trial claims under the seventh amendment were allowed if the action was at law, e.g., Union Ins. Co. v. United States, 73 U.S. 759 (1867), and denied if the suit was in equity or otherwise not at law, e.g., Luria v. United States, 231 U.S. 9 (1913). It is suggested that penal proceedings brought by the Government should be considered initially if not exclusively as sixth amendment cases.

9371 U.S. 277 (1866). For a thorough discussion of the origins of the penal-regulatory distinction and its relation to substantive due process, see Comment, 32 U. CHI. L. REv. 290 (1965).

94372 U.S. at 213. 
bill of attainder clauses. If the statute aims solely to punish or deter behavior, it is invalid, but if the statute serves a broader regulatory purpose it is sustainable. In Trop the Chief Justice put a complicated matter as simply as possible:

If the statute imposes a disability for the purposes of punishment-that is, to reprimand the wrongdoers, to deter others, etc. - it has been considered penal. But a statute has been considered non-penal if it imposes a disability, not to punish, but to accomplish some other legitimate governmental purpose. The Court has recognized that any statute decreeing some adversity as a consequence of certain conduct may have both a penal and a non-penal effect. The controlling nature of such statutes normally depends on the evident purpose of the legislature. The point may be illustrated by the situation of an ordinary felon. A person who commits a bank robbery, for instance, loses his right to liberty and also his right to vote. If, in the exercise of the power to protect banks, both sanctions were imposed for the purpose of punishing bank robbers, the statutes authorizing both disabilities would be penal. But because the purpose of the latter statute is to designate a reasonable ground of eligibility for voting, this law is sustained as a non-penal exercise of the power to regulate the franchise. 95

Employing the penal-regulatory distinction is a way to resolve sixth amendment cases, but it has substantial drawbacks. First, if the purpose of the jury is to protect the individual, he needs that procedural protection whether or not the statute affecting him is imbued with a broader regulatory purpose. Second, the distinction has its primary use in the ex post facto cases, to determine whether a statute should be permitted to have a retroactive effect. For instance, the voting statute in Warren's example would be permitted to apply to those who robbed banks before its enactment because it exists to regulate elections, while a statute decreeing imprisonment for bank robbers could not be applied to those who robbed banks before its enactment because it has a penal purpose. But the policy issues involved in determining whether a statute should have retroactive effect may be quite remote from policy questions about requiring a jury trial. Thus, one might term a voting provision "regulatory" when deciding whether those who robbed before its enactment may be disenfranchised and yet term the provision "penal," when deciding whether conviction by jury is required to disenfranchise them. Because of the discrepant policies, the ex post facto cases provide misleading analogies. Third, a conclusion that a statute is regulatory would bar a jury trial even when jury trials would not impair the regulatory

95356 U.S. at $96-97$. 
process. Yet the importance of protecting that regulatory process was probably a major reason for labelling the statute regulatory and thereby allowing Congress to "regulate conduct free from restrictions that pertain to legislation in the field technically described as criminal justice." $96 \mathrm{~A}$ final drawback is the difficulty of deciding whether the controlling purpose of a statute is penal or regulatory. The manifold criteria used by the Court are sometimes contradictory because most statutes imposing punishment have regulatory purposes as well; the object of a statute punishing bank robberies, for example, is to protect federal banks as well as to discomfit bank robbers. As an upshot, the debate about characterization is likely to be sterile and artificial, as it was in Mendoza, ${ }^{97}$ becoming ultimately a battle over conclusory categories while the real reasons for decision go unspoken. These real reasons, such as the impairment of vital regulatory aims, will be discussed later.

Another formulation would posit that juries are required when a civil disability is used as a means for punishing behavior already forbidden and punished as criminal. The additional non-criminal disability often embodies a legislative subterfuge to punish without juries crimes that ordinarily have jury trials. Requiring a jury, then, is simply a matter of not being misled by labels. ${ }^{98}$

An example of this sort of looking past labels occurred in Lipke v. Lederer. ${ }^{99}$ There, Congress had imposed a special tax on sales of liquor that already were criminally proscribed under the Volstead Act. Concluding that the purpose of the tax was to punish liquor violators and not merely to raise revenue, the Court held that Congress must have intended the penalty to be enforced only after a criminal jury trial, which was constitutionally required.

While prevention of legislative subterfuge should be taken into account, the additional punishment rationale would be an inadequate foundation for a general theory of the sixth amendment jury trial requirement. ${ }^{100}$ It could not explain the use of juries in cases that are

96 Trop v. Dulles, 356 U.S. 86, at 125 (1958) (Frankfurter, J., dissenting).

97372 U.S. at 167-84, 190-91, 213-15.

98 "How simple would be the tasks, of constitutional adjudication and of law generally if specific problems could be solved by inspection of the labels pasted on them!" Trop v. Dulles, 356 U.S. 86, 94 (1958).

99259 U.S. 557 (1922). Cf. United States v. LaFranca, 282 U.S. 568 (1931). But cf. Helvering v. Mitchell, 303 U.S. 391 (1938).

100 An important idea sparking the expansion of the sixth amendment is that legislatures have a broad selection of sanctions to punish wrongdoing. Accordingly, a general theory should postulate that the constitutional right of trial by jury should not depend solely on the legislature's choice of sanctions.

Possibly all the Court held in Mendoza was that denationalization could not be imposed in addition to criminal sanctions to punished draft evasion since denationaliza- 
punished only by traditional criminal means. Even if it were used only as an explanation for expanding the scope of application of the amendment, the results would be too fortuitous. If the behavior which is punished by both criminal and non-criminal means should by legislation cease to be a crime, the non-criminal sanction under this theory could be imposed without a jury. Yet there might be continuing reasons for providing a jury trial despite the fortuitous removal of the criminal sanction.

So far, it seems clear that an acceptable general theory should treat the imposition of penalties-in the sense of disabilities for wrongdoingas the threshold for requiring jury trials, but should reject the elaborate penal-regulatory distinction. It should also prohibit legislative subterfuge which punishes crime without a jury trial, by resort to non-criminal sanctions.

But not all penalties trouble the court; it is the severe penalty that evokes the impulse for a jury trial. Denationalization in Mendoza is called "the drastic, the truly terrifying remedy."101 The Court characterizes American citizenship as "one of the most valuable rights in the world" and stresses that its deprivation has "grave practical consequences, ... 'not the loss of specific rights . . but the loss of a community willing and able to guarantee any rights whatsoever. . . "'102 Past cases on citizenship brought forth similar expressions of deep concern. ${ }^{103}$ So too, an unprecedented severity of punishment for contempt, ranging to three years imprisonment, led the Barnett minority to suggest that all serious criminal contempts be tried by jury and led the majority to suggest that contempts tried summarily could not be punished severely. 104

The severity of a penalty could serve as the sole criterion for the availability of sixth amendment juries. The test would be simple-no

tion did not have an alternative regulatory purpose. "Our conclusion from the legislative and judicial history is, therefore, that Congress in these sections decreed an additional punishment for the crime of draft avoidance in the special category of cases wherein the evader leaves the country. It cannot do this without providing the safeguards which must attend a criminal prosecution." 372 U.S. at 184 (citing Lipke v. Lederer, 259 U.S. 557 (1922), and United States v. LaFranca, supra note 99). See also $i d$. at 170 n.30. But Mr. Justice Goldberg stated four times (see note 65 and accompanying text) the broader holding that all penalties require jury trials and Justices Brennan and Stewart accept that proposition as the holding. 372 U.S. at 199, 206-07.

101372 U.S. at 188.

102 Id. at $160-61$.

103 Trop v. Dulles, 356 U.S. 86, $101-02$ (1958); Perez v. Brownell, 356 U.S. 44, 64-65 (1958) (dissenting opinion); Nowak v. United States, 356 U.S. 660 (1958); Schneiderman v. United States, 320 U.S. 118, 122 (1943).

104 United States v. Barnett, 376 U.S. 681, 695, 751-52 (1964). 
severe penal sanctions may be imposed without a criminal jury trialthough it would trample the traditional configurations beyond recognition and involve mass overrulings. ${ }^{105}$ The job of choosing and applying criteria to determine the requisite severity would be difficult, but no more taxing than deciding whether a punishment is cruel and unusual. Deportation and denaturalization have already been characterized as severe in Court decisions. ${ }^{106}$ Juvenile incarceration, loss of right to pursue a livelihood, heavy tax or administrative penalties and other disabilities might be found severe enough to warrant jury trials.

But were severity the exclusive touchstone, great damage might be done to the ability of government to sustain itself through revenues and to carry out programs of public concern. If tax penalties for failure to file were deemed severe, jury trials would be required for their assessment and the consequences would be devastating. In a recent year delinquent filings for which penalties could be imposed numbered one and one-third million. The Commissioner proceeded against nearly one million taxpayers. In contrast, only 7,000 criminal cases of all sorts were instigated by IRS.107 Making jury trials available for one million assessments would nullify the few sanctions that make self-assessment effective and thus strike at the heart of our voluntary tax system. Other examples of impairment of administration are equally apparent. ${ }^{108}$

A general theory should take account of the impact of jury trials on effective governmental administration. ${ }^{109}$ No doubt absolute rights granted by the Constitution should not be sacrificed for administrative expediency, but the right to a jury trial in areas that border the criminal law cannot fairly be termed absolute, if indeed any right can.110 The right exists, most poignantly, only insofar as the Court says it does; history and precedent stand firmly against it and policy offers little justification. A sense of caution and judicial propriety ought to temper the Court's zeal for protecting the individual where that zeal has such unsure foundations.

105 For cases that might require overruling, see notes 12-19 supra.

108 Nowak v. United States, 356 U.S. 660 (1958) (denaturalization); Bridges v. Wixon, 326 U.S. 135 (1944) (deportation); Schneiderman v. United States, 320 U.S. 118 (1943); Fong Yue Ting. v. United States, 149 U.S. 698, 740 (1893) (dissenting opinion).

107 Coma's of INTERNal Revenue, ANNuAL Report 35, 40 (1961).

108 "The interposition of the courts in the appraisement of importations, would involve the collection of the revenues in inextricable confusion and embarrassment." Bartlett v. Kane, 57 U.S. 263, 272-73 (1853). Similarly, effective military discipline depends in large measure upon court-martial proceedings.

109 Cf. Packer, Two Models of the Criminal Process, 113 U. PA. L. REv. 1 (1964).

110 Compare Mr. Justice Black in Reid v. Covert, 354 U.S. 1, 14 (1957), with Address by Dean Griswold, Absolute Is in the Dark, Leary Lecture, University of Utah Law School 1-4, 20 (1963). 
The Court itself has at times studied the impact on administration when jury trials replace existing procedures. ${ }^{111}$ Thus, in Toth, the Court concluded:

It is impossible to think that the discipline of the Army is going to be disrupted, its morale impaired, or its orderly processes disturbed, by giving ex-servicemen the benefit of a civilian court trial when they are actually civilians. Army discipline will not be improved by court-martialing rather than trying by jury some civilian ex-soldier who has been separated from the service for months, years or perhaps decades. ${ }^{112}$

Mr. Justice Frankfurter, concurring in the result of Reid $v$. Covert put it this way:

We must weigh all the factors involved in these cases in order to decide whether these women dependents are so closely related to what Congress may allowably deem essential for the effective "Government and Regulation of the land and naval forces" that they may be subjected to court-martial jurisdiction in these capital cases, when the consequence is loss of the protections afforded by Article III and the fifth and sixth amendments. ${ }^{113}$

In Kinsella $v$. United States ex rel. Singleton and its companion cases, Mr. Justice Clark removed dependents and civilian employees from court-martial jurisdiction, in part because the number of crimes generated from those classes was small, and, in the case of employees, because the services could solve the problem of discipline by making submission to court-martial jurisdiction a condition of employment. ${ }^{114}$

On the basis of considerable analysis, Mr. Justice Goldberg stressed in Mendoza that "our holding today does not frustrate the effective handling of the problem of draft evaders who leave the United States."115

In Barnett, the majority showed an inclination to expand the jury trial to severely punished contempts, but refused to provide jury trials in all contempt cases because that step was felt to impair effective judicial administration. The Court summarized its feelings by quoting from an old Mississippi case:

The power to fine and imprison for contempt, from the earliest history of jurisprudence, has been regarded as a necessary incident and attribute of a court, without which it could no more exist than without a judge. ... A court without the power effec-

111 But see Reid v. Covert, supra note 104, at 14.

112350 U.S. at 22.

113354 U.S. at 44 (Emphasis added).

114361 U.S. 234, 246-47, 278, 281 (1960). See notes 56-58 supra.

115372 U.S. at 184-85. 
tually to protect itself against the assaults of the lawless, or to enforce its orders, judgments, or decrees against the recusant parties before it, would be a disgrace to the legislation, and a stigma upon the age which invented it.116

Even Mr. Justice Black, in dissent, agreed that imprisonment for so-called civil contempt is permissible to secure compliance with a court order because of the need for "immediate action."117

If the Court accepts responsibility to consider a broad range of interests an appropriate theory for criminal jury trials might be worded as follows:

The sixth amendment provides for criminal jury trials in all cases where the government imposes severe sanctions that punish wrongdoing except where juries would gravely impair effective administration.

Such a theory would direct the Court's attention to the following issues: (l) What sorts and degrees of sanctions should be considered severe? Certainly the old restriction of the sixth amendment to death, imprisonment and fines would be rejected. Moreover, sanctions do not always have the same effect in different circumstances; intelligent distinctions might be made, for example, between deportation of a thirty-year resident and deportation of a wet-back caught a mile inside the border, or between revocation and suspension of licenses. (2) What advantages do existing procedures have for the individual and the government? For example, juvenile proceedings are supposed to benefit the juvenile and the government because of privacy, intimacy and greater chance for rehabilitation. License revocation proceedings often require expertise concerning legal ethics, medical techniques, or the properties of radio waves. Assessment of revenue penalties by revenue collectors aids the government in speed and cost. (3) What impact on effective administration would result from replacing present procedures with jury trials? In the case of tax, the impact would clearly be unacceptable. ${ }^{118}$ In the case of juvenile proceedings, courts would have to estimate whether existing procedures are actually accomplishing the administrative purpose of keeping juveniles out of the criminal system. If not, there is little harm done in requiring jury trials. In the case of license revocation, courts would have to guess in each instance how the jury requirement would affect governmental or professional supervision of the licensed profession. (4) Is the present procedure unsatisfactory for reasons that could be remedied without imposing jury trials? For example, deportation and denaturalization have

116376 U.S. at 699-700, quoting Watson v. Williams, 36 Miss. 331, 341-42 (1858).

117376 U.S. at 728 n.6.

118 See text accompanying note 107 . 
recently been held to require not only notice, hearing, and right to counsel, but also a clear and convincing quantum of proof by the government. ${ }^{119}$ Or again objection to the lack of independence of courts-martial might be satisfied by a civilian court even though it did not use a jury. ${ }^{120}$ (5) Is the sanction employed solely as an additional punishment for crime? If a legislative subterfuge is suspected, the judicial response is likely to be a jury trial requirement. This response seems appropriate; to prevent such a subterfuge, the presumption of need for a jury in these cases ought to be raised even if the sanction standing alone without coexisting criminal penalties would not have been grave enough to warrant the presumption. In case the sanction is severe, its use as an additional punishment would merely strengthen the presumption.

If Mendoza were analyzed in accordance with this approach the result probably would be the same but the reasons would be different. First, the severity of denationalization would not merely make the case important, but would establish a presumption that denationalization could not be imposed without a jury trial. Second, greater emphasis might be placed on the existence of criminal sanctions for punishing draft evasion. If denationalization had no purpose other than to punish draft evasion, it would be treated as an illegitimate subterfuge to punish crime without the protection of a jury trial. The presumption in favor of a jury would thus be strengthened.

Furthermore, the impact of the jury trial on the administration of the armed forces would have to be scrutinized even more deliberately than it was. The sensible conclusion-that those who stay abroad to avoid trial satisfy the purpose of denationalization since self-imposed exile bars them from enjoying the fruits of a victory which others won-would have made clear that the presumption for jury trials had not been rebutted. But other possibilities would also need careful consideration. It might be asked whether the denationalization statute was objectionable primarily because it lacked a jury trial or rather because the initial determination of denationalization was made without notice, without hearing, and by administrative officials in interested departments. In the latter case, a statute that cured these defects might be acceptable, even if it did not provide for a jury trial.

Analyzed this way, the Barnett result might still be correct. Let us assume, as the minority did, that punishment for contempt has become severe. If, as the majority states, the summary adjudication of out of court contempts goes to the core of a court's ability to administer justice,

119 Bridges v. Wixon, 326 U.S. 135 (1944); Schneiderman v. United States, 320 U.S. 118 (1943); cf. Nishikawa v. Dulles, 356 U.S. 129 (1958).

120 See Reid v. Covert, 354 U.S. 1, 87-88 (Clark, J., dissenting). 
then punishment of even greater severity might not require a jury trial. In addition, if summary punishment of out of court contempts were not thought to outweigh severe sentences, other kinds of contempt still might be punishable summarily because of their greater significance for judicial administration. 121

Finally, it may be helpful to apply this theory to a perplexing lower court case dealing with a telephone disconnection which was ordered by the Justice Department because of alleged illegal use. In Telephone News System, Inc. v. Illinois Bell Telephone Co. ${ }^{122}$ the telephone customer sought an injunction against discontinuance of service by Bell. Bell had given notice of impending disconnection pursuant to an order of the Justice Department which later intervened in the injunction proceeding. The governing statute provided that such orders could be given when an appropriate law enforcement agency thought that the facilities were used for illegal gambling. Here, the customer was receiving horse race results from a national news service and disseminating the results by telephone recordings, a use of the phone which violated an Illinois gambling statute. The customer alleged in part that the federal statute violated his rights under the fifth and sixth amendments, citing Kennedy v. Mendoza-Martinez.

The three-judge district court applied the test used in Mendoza and found that the statute was not penal but regulatory since it aimed to prevent crime, not to punish it. One judge in concurring could not suppress doubt:

[W] here the forfeiture of property will be fatal to the business life of the party involved and substantially greater and more severe than the maximum punishment which could have been imposed in a direct criminal proceeding, labelling it preventive and non-penal is a sophistry which hardly warrants the abrogation of the Constitutional protections which are the keystones of American criminal justice. ${ }^{123}$

Under the approach suggested in this comment a jury trial would prob-

121 Contempts might be classified in terms of their significance for judicial administration. Perhaps the need for summary proceedings in civil contempt is the greatest, since they allow great variation in the sorts of affirmative action the court can successfully order. Next on the scale of necessity might come contempt in court, since decorum in the courtroom is closely tied to giving the parties due process of law. Criminal contempt out of court would come last since the harm of such disobedience is arguably no greater than when legislation is violated. Furthermore, civil contempt might be viewed as less severe than criminal contempt, although in theory imprisonment can be perpetual, since the term is not fixed by law but only by the stubbornness of the victim.

122220 F.Supp. 621 (N.D. III. 1963).

$123 I d$, at 643 . 
ably be required. The sanction is penal in the common sense of the word: a governmentally imposed disability for crime or wrongdoing. It can fairly be termed a severe sanction for the reasons mentioned by the concurring judge, although the severity is obviously not so great as that of denationalization. The presumption that a jury trial is needed can probably be established. Also there would be no hesitation in calling the statute sanctioning disconnection a legislative subterfuge to punish crime without the traditional criminal safeguards. For the assigned regulatory purpose of preventing crime is no different from the purpose of anti-gambling statutes that impose traditional sanctions of fine and imprisonment. The subterfuge would strengthen the presumption of need for a jury, or if disconnection were not considered severe, would assist in raising the presumption.

On the other hand, it appears that administration would not be gravely affected by requiring a jury. The sanction does not arise from the pursuit of some important regulatory objective such as tax collection, licensing, or even the rates and conditions of utility service. The number ${ }^{124}$ of telephone "bookie joints" cannot be large enough to require simplified procedures. Furthermore, resisting an injunction may cost the government even more money and time than an orderly criminal prosecution. Since replacing the present procedure appears to incur few disadvantages, the presumption would seem unrebutted.

\section{IV.}

Cases such as Telephone News will test the Supreme Court's ingenuity in devising a harmonious solution to the criminal jury trial question. The comfortable formulas which formerly restricted access to juries stand rejected by the court-martial cases, Mendoza, and Barnett. But the Court's strong, if questionable, impulse to extend the right to juries has yet to be supplemented by constitutional guidelines. This comment has sought to identify the variety of interests-governmental and individual-that the Court should consider in fashioning these guidelines.

124 See Kinsella v. United States ex rel, Singleton, 361 U.S. 234, 246 (1960). 